\title{
Translanguaging, Heterodiscourse and Multilingualism in the Teaching-Learning of Languages: An Reflection
}

\author{
Sweder Souza \\ Post-Graduate Program of Letters, Federal University of Paraná \\ Rua General Carneiro, 460, $10^{\circ}$ andar - sala 1018/1019, Curitiba, Paraná, PR, Brazil \\ Tel: 55-41-99765-6322Ｅ-mail: swedersouza@gmail.com
}

Received: June 9, 2018 Accepted: July 9, 2018 Published: July 10, 2018

doi:10.5296/elr.v4i2.13268 URL: https://doi.org/10.5296/elr.v4i2.13268

\begin{abstract}
One of the central points for the concept of heteroglossia is negotiation, the social negotiation that is central to the heterodiscourse, since all the time one is negotiating to place of saying and, still, negotiating to position, in the interaction, in the own language. One issue that has become increasingly strong in translanguaging studies is the understanding that if one is negotiating tension, one is actually negotiating power relations. According to this context, this work aims at a theoretical-methodological reflection of some concepts that can, also to dialogism and interactionism, to contribute significantly to the practice and to the teaching-learning of languages.
\end{abstract}

Keywords: Language, Teaching, Translanguaging, Multilinguism, Heterodiscourse

\section{Introduction}

In Brazil, since 1985, educators and researchers have been pointing to the urgency of making significant changes in the teaching-learning process of languages in basic education. From then on, several curricular proposals began to echo in the national scenario through state guidelines.

In 1997, the National Curricular Parameters (NCPs) - considered a tool for the educational system - incorporated some of these state plans and presented a resizing of the current theoretical and methodological foundations. These documents recommended the need to subsidize classes in an interactionist conception of language (Bakhtin, 2006).

In this conception, school work only makes sense if articulated to social linguistic uses and, therefore, should prioritize practices of reading, writing and orality, permeated by reflections on the language. 
According to this context, this work aims at a theoretical-methodological reflection of some concepts that can, also to dialogism and interactionism, contribute significantly to the practice and pro teaching-learning of languages.

\section{Translanguaging and Heterodiscourse Views}

One of the central points for the concept of heteroglossia (Note 1) is negotiation, a social negotiation that is central to heterodiscourse, because all the time one is negotiating a place of saying and, still, negotiating a position, in interaction, in one's language.

An issue that has become increasingly strong in translanguaging studies (Note 2) it is the understanding that if one is negotiating tension, one is actually negotiating relations of power.

The translanguaging is going to be transformative in certain aspects, but it is not salvaged. Although some authors say that translanguaging will "give voice to those who have no voice", it is actually a voice space for those who are muted, that is, for speakers of muted languages. So when you start to understand that this is also translanguaging contingency space of the subject's action, the individual agencies, it is seen, rather, as a processor.

These spaces of individual agencies do not nullify power relations. This means that no matter how negotiated, negotiation does not imply harmony, it does not imply that everyone wins the same thing, does not imply a consensus at all, but rather a negotiation rather than an imposition.

In this sense, it is not possible to look simply at these spaces of interaction as spaces of reproduction, but rather as spaces of agency of the subject. This means that power relations will determine the subjects' social positions. Likewise, as a researcher and analyst, one is not outside this process of interaction, precisely because it is responding to a statement.

Thus, as an analyst, one is looking at this statement seeking to respond to it. Therefore, there is the interaction on the part of the analyst and the researcher, for being interacting with these subjects, being also, in this context.

Remembering the language proposal as Kaleidoscope (César, 2007), who is more authorized than the speaker to speak the language? The change and the non-fixation of the look, in this sense, is justified by the subject's gaze, that is, by positioning, a priori, not to leave the subject, previously silenced, but rather to use its real and interactive contribution.

The researcher has the opportunity to position himself and this position, this movement of looking at the language like Kaleidoscope, provides a position of "upwards", that is, part of the practice of the speaker to compose his corpus of research, let it speak / theorize about it, making an opposite move and do not tie aside (only) the theoretical questions already debated about language.

To conceptualize a language from the speakers, may be a little more difficult for acceptability, but this is (another) negotiation from which the researcher, the analyst, the teacher, enter into tension.

In this sense, according to the objective of this study, a choice was made in this case to 
discuss translanguaging from heteroglossia / heterodiscourse, as a way of reflecting on other meanings of language that can contribute to teaching-learning of languages.

Understanding that something has already been said about language between the 1920s and 1950s, which is now being taken up again, receiving other names, with other elements included, with new elements included, but which basically goes back to an issue already debated. Thus, this work, as already said, aims at a review of such concepts.

The choice of going to translanguaging is to enter into new paradigms, such as the agentivity of the subject, of the participants in the interaction and the interaction fact to be a historically situated partner. Therefore, one makes choices of certain theoretical perspectives to follow in the teaching of languages.

The question of translanguag of heteroglossia and heterodiscourse then be justified as language is a set of resources available to the speakers, which are built and loaded ideologically. I.e. there is a set of resources, for example, you have to see how Italian, or what is named as Italian, having all these resources available, knowing that these resources are loaded value, ideologically.

But in interaction, it is possible to mobilize all this resource, whether oral, verbal, visual, imagery, body, gesture language etc. Therefore, there is no way to put the languages in "boxes", precisely because it has as idea that as a speaker, one has the availability to use the various resources. And depending on who you interact with, certain resources are mobilized.

In this sense, it is difficult to think that one has: Italian, Portuguese, French, for example, if one has a whole repertoire at disposal, leaving, also, to be only linguistic, becoming semiotic in the broadest sense of the term.

The notion of sign, in this case, is charged ideologically, the word ideologically charged, having not only the word available, but several other language resources which, when one is in interaction, "opens the basket" and is disposing of everything that is available to build meaning.

\section{Multilingualism: Another Key-Meaning for Teaching and Learning}

Pointing to some slips from the perspective here followed, in Cox and Assis-Pettersson (2007) there seems to be only one concept of interculturality, which is denied and then "replaced" by transculturality, since interculturality would not be enough.

It would, then, be similar to saying that linguistic diversity presupposes putting all languages - languages are different from each other, certainly - to relate as if they were on the same level, all of them being worth the same.

In this sense, thinking about this diversity, when speaking in multilingualism it is necessary to think that there are relations of power, then, yes, there are hierarchies between languages.

According to Cox and Assis-Pettersson (2007), when “(...) linguistic pluralism accentuated the presence of many languages (from then on, whenever we refer to languages we are also thinking of varieties), but we say nothing about nature other of each language. When we 
speak of linguistic diversity we emphasize the existence of many languages that are different, heterogeneous and often immeasurable. We admit that languages are many and qualitatively diverse. This assumption anchored the linguistically relativistic stance that polemizes with the Enlightenment stance. If for the Enlightenment, among the grammarians, languages are divided between civilized and barbarian, for relativists, among them linguists, languages are unique, each with its internal structure. Relativism fosters the discourse of the right to difference, tolerance and democracy in society. It also feeds the preservationist discourse (Cox, 2007)".

When the authors propose this notion of transglossia, they propose to say that these previous concepts, all presuppose closed systems, however, there are ways and ways of speaking of linguistic diversity, multilingualism, interculturality, bilingualism and diglossia, categorical in many ways, seeming to deal with concepts that are closed.

It is necessary to question the notion of language that is guiding Linguistics. In this sense, it is necessary to revise the notion of language that has historically oriented Applied Linguists. From this point of view, this path made by the authors is quite important, thinking, historically, that these conceptions have to be revised and go to a conception that is non-systematic of language.

From the point of view of dialectal variation, for example, the notion of dialect is of the varieties of a certain official language, that is, to think the language as a system. In this way, this dialectal variation has to do with the concept of variations within the same language. Which, anyway, is being looked at as a system.

In this sense, for example, what is best known and heard is in relation to the Caipira dialect, however much it is recognized as a dialect, it closes and excludes the historical, social and cultural issues of a particular people and only refers the language as a dialect, it takes place there, certain social determinism.

This problem seems to come from Sociolinguistics, which comes from a closed view of Linguistics, but it is an attempt to say that there is a hierarchy, a certain social organization that is linked to the language of this social organization, that is Sociology - where one had categories, and a correlation with the language would be sought in relation to these fixed categories.

This, of course, has a series of implications because it ends up dealing with the old categories that are known as fixed categories and that are racial, generational, gender, each one thought of and one of them can be geographic. It is also placed in "boxes", but these categories are not fixed, even generational, because it negotiates to which generation one belongs, for example.

Another point, spoken here from overseas, what is widely heard is to say that African languages are dialects. In Nigeria, English is the official language, but the rest of the languages are treated as dialect. Do you speak English and two other dialects? No, they are two languages. 
This construction we see today, of treating languages as dialects, often forgets that this construction comes from a construction of the modern European nation state.

Modern European states will use language as an element of unity, that is, it is a language, and that language makes all the others become dialects. So that language, which takes the place of power, which is the place of unity, of the construction of national unity, simultaneously silences multilingualism and silence, basically calling it a dialect, when it does not erase, , possibilities of hybridization, as is the every one of Portunhol, for example.

In this sense, if you insist on systematization, you will automatically enter the fixation. The idea is fluid, flowing, alive. Not systematic. The Linguist has the desire to systematize, of description. From the point of view of the Linguistic Policy to have the description, there are instruments of Linguistic Policies, that are dictionaries, the grammars, of this systematized writing, that can be interesting.

So it is complex, at the same time that systematization implies almost inevitably fixation, describes fixed, and the measure in which these instruments are constructed the effect is fixation. It is necessary to know the different Portuguese Languages, different Spanish, different Hybrid Languages. If we look at the same point, we will return to the system, to the static.

\section{The Language and the People}

There is translanguaging in all language spaces. You can not think of any of these issues without thinking about using them. When languages are named, languages are invented, separated with our eyes.

Many African languages have different names and many linguists treat as different languages, but speakers speak the same languages. It has African and Indigenous language which speakers treat as different languages and linguists as the same. This means that there is no specific number of languages.

The essence of linguistic ideology is thus laid down. What is it that has this name, what has become that is named this way, what is involved in this process? At this point, Cox and Assis-Pettersson (2007) treat language as a process of hybridization, so if you think about these processes do not take language as a system.

Thus, if one has a notion of the language of science that needed to be, by the very notion of science in force, at that moment, a closed system and, from there, if they had the varieties. But how were these varieties treated? The authors point to those varieties that are limited, made so far, proposing this notion of thinking heteroglossia as broken systems or non-systems.

While in César and Cavalcanti (2007), the theme of linguistic diversity is treated in another perspective. The language like Kaleidoscope, has dashed lines that point to the non-fixation of the borders of the languages, that is, they do not point to "closed boxes", but, for the borders existing in the languages, since it is not possible to think in a language that, at some point, be pure. You have to think of miscegenation. 


\section{MInstitute Macrothin}

The effect of the tongue with Kaleidoscope, refers to something in movement, alive, always in constant change. Everything that is permeated by the Kaleidoscope's look changes. Basically, one can no longer be guided, within Applied Linguistics, by the language conception proposed by Linguistics.

All this complexity takes into account someone who was not being considered until then, that is, the look at the other, the subject of the language. The tendency is to come to conceptualize what is language, never the other way around, letting the subject speak.

In view of this conception, it is necessary to know the vision of the subject, the agent of the language in use, looking first at their vision. In this sense, the research in Applied Linguistics must also encompass the perspective of the subject and not only that of the researcher. The researcher has to talk about the perspective of these participants.

The tendency is to see the language in this way, since all the science was built from that appointment, which defined these borders and these units of language. But rather are negotiate with that ethnic identity, for example, because you have to understand that we are negotiating all the time.

This subject that conceptualizes language, speaks in the relationship with other subjects, not only between subjects and researcher, teacher, speaks from a place of his belonging, in the case of the authors' research, in the relation of the Indigenous with other Indigenous people and the relation of Indigenous people with non-Indigenous people, in this case, an ethnic voice.

Thus, when necessary, one must move around and when this occurs there is also the need for negotiation. Thus, assuming the language as Kaleidoscope, one glances at the relationships that are at stake for these subjects. When one looks at the language from the point of view of the speaker, one has movement all the time, not being able to look at language as a system.

For example, looking at the subject, we have all the negotiating issues, such as: what language is this that is circulating in the classroom, for example, what is taught, but what language do students want to learn? The subject is social, with everything that has of the conflicts and contradictions in relations of power and tensions of this social. And it is this place that has to be occupied, with all its contradictions and tensions.

Thinking of a subject that is within an institution and that has a relation to the relations of power that are in the institutions, but this subject is not simply dominated by this institution, it is an agent within that space, it transits between spaces and this traffic will cause these relationships to be reviewed, all the while looking at micro relations. Negotiating, thus, what the subject says, not negotiating what he can say. For if not, the subject can only negotiate what he can say, but, rather it is observed that the subjects negotiate confronting a power to say, that is, he negotiates what he is saying.

In this sense, the set of subjects' repertoire consists of several semiotic resources. In a Dialogical Discourse Analysis (DDA), it is basically understood that utterances are not isolated from other utterances. An DDA, therefore, takes a statement and will understand that 
this statement is in relation to so many other statements.

So what has been written, for example, is in relation to other texts. To say things, it is necessary to converse with a number of other texts produced.

In Dostoevsky's Problems of Poetics, Bakhtin (2010), makes an analysis of his poetic relating him Dostoievsky writer, literary, journalist, religious. this relation is given through access, of several moments, it refers to other texts of the Dostoyevsky that not that text that is in focus.

It is not the question of analyzing just one text. Not in view of a written standard, how can be confused, but rather establish relationship, quite different from comparing, but, in dialogue. Just as in various instances of the subject, whether in religious practice, university, etc., many things are better understood than is said, for it relates to other discourses.

The idea is not to be or not to be coherent, but to dialogue. We do not look for what has or is not common in the writings, but we observe, as an analyst, that there are tensions between the sayings. And in moments you can see enormous contradictions, because it depends what is at stake. In a religious practice, for example, identity is at stake, but at the university level it is not at stake, thus negotiating which identity is highlighted in that context.

Heterodiscourse is used throughout social practices. As in the named languages, because it separates, naming languages, for example, Portuguese, can be looked at by new, broader semiotic repertoires, such as looking internally within that named language, and in the multiple semioses in which sense is constructed. For the Bakhtin Circle, a verbal sign is a sign, so it is semiotic.

And often, the work in Linguistic Policy, for example, attributed the language as a discrete, more closed system. In this sense, it is necessary to think about other policies, especially on education. Above all, because every linguistic question, everything that is said about the language and about the speakers, is related, above all, to the speaker and everything that relates to how subjects are built.

In this sense, it is necessary to think in Linguistic Policies in a broader way, especially to think the teaching of languages in a less closed way. How, then, do we teach language (s) when we think of language in a broader way? How to deal with language not only from a theoretical perspective, but when you teach, what is done?

When there is such a question, one possibility is heterodiscourse and / or translaguaging, it is basically said that one is looking, to teach / assist, in organizing the semiotic resources that they can construct, including the teaching process as a construction process or expansion of these semiotic resources.

Thus, when taught in this perspective of language is dealing with semiotic resources. Being these semiotic resources includes the verbal language, language in the strict sense. When one says that one has taken into account in teaching what the speaker says is a language, and may be a lot of things, but when one says this, the idea is that now it is expanded, in the sense of understanding that one has everything this ample repertoire, all those resources that are linguistic, but in teaching, involve other resources of languages, other than just verbal. 


\section{Considerations}

According to some points, briefly, raised in this work, if the subject's language is negotiated in the school, for example, is negotiated with this other, not being able to leave it out, once identity is negotiated, we must deal with two, ten, twenty, who are in negotiations in numerous positions, which are also in negotiations.

So, how is it about language looking at subjects, both in the research context and in the context of teaching? We negotiate positions in any instance, in the context of the classroom, on the street, in the market. What actually happens in life and give us subsidies to think about how to transpose to teaching issues, proposing meaningful practices in the classroom?

This language, or rather, these social languages, compose the semiotic repertoire of the subjects. In this sense, any materialized ideological representation, be it verbal, visual, sonorous, gestural, etc., must be taken into account. For Bakhtin (2006), the sign, the word, is the ideological sign par excellence, but it does not take the place of the other signs.

So sound sign is music, the word may be together, but it is not taking the place of. It builds meaning with, but does not replace. So, all of these resources that are mobilized are ideologically loaded and they mobilize the subjects, so we talk about indexicality.

The notion of indexicality is anchored in a question of position, of pointing to, but when this is used, where the subject stands and where do I position the other in the interaction?

In Speech Genres, Bakhtin (2006) says that one learns the words of the statements of others, plunges into the living stream of communication. What is meant by this meaning? It seems that, once the constituent subjects of the world come into contact with these innumerable statements in their daily lives, and apprehends the words, giving them value tones for them, from what is heard from the other.

When Bakhtin (2006) speaks of multivocality in relation to heterodiscourse, he says that Dostoevsky's ability to listen to what was circulating socially and to mobilize these different discourses that were circulating socially, Bakhtin speaks about him from someone who brings these different voices into the novel.

So he has the different characters that will position himself valiantly in a debate, about God, for example, about what is right and wrong in killing or not killing, and there is a religious vision, a legal vision, a vision social, different voices, addressing this theme.

It precisely points to this as heterodiscourse, since these different voices carry different values. So the heterodiscourse is above all a difference of value, it is not in form, it is not in ideology. The utterance of the same subject is hybrid, for when he enunciates he has an evaluative statement of it, but also recognizes an evaluative tonality that comes from another place. Social language has nothing to do with form, above all, with value, as a priority. Hence the preference for heterodiscourse.

Likewise, discourse is understood as "[...] the language in its concrete and living integrity, and not language as the specific object of linguistics, obtained by means of an absolutely 


\section{Macrothink}

legitimate and necessary abstraction of certain aspects of concrete life of discourse (Bakhtin, 2006).

Thus, if language as a discourse is understood, it will not be possible to unlink subjects, social spheres, ideological positions, etc., that is, if the concept of language is linked as an object of linguistics one cannot have dialogic relations, since this relation cannot occur among the elements in the language system, such as words, prayers, morphemes, etc.

Therefore, since the Bakhtinian presuppositions are linked to the axes of teaching and articulated with practices of language, these other conceptions together can infer strong traits of contributions to the practice in the classroom, towards the understanding of the functioning of the language. The subjects perform strategies of reading and writing and at the same time reflect the questions of language analysis in an interdependent relationship according to the apprehension of the linguistic knowledge that we interact in the most varied sociodiscoursives situations.

\section{Acknowledgement}

This partial work is being funded by the Coordination of Personal Improvement of Higher Education (CAPES), within the scope of Postgraduate Research / Master in Letters / Linguistics Studies of the Federal University of Paraná.

\section{References}

Baktin, M., \& Volochinóv, V. (2006). Marxismo e Filosofia da Linguagem: Problemas fundamentais do método sociológico na ciência da linguagem. Tradução Michel Lahud e Yara F. Vieira.12ed. São Paulo: Hucitec.

Bakhtin, M. (2010). Problemas da Poética de Dostoiévski. Tradução Paulo Bezerra. 5th. ed. revisada. Rio de Janeiro: Forense Universitária.

Brasil. (1998). Parâmetros Curriculares Nacionais (PCNs). Brasília: Ministério da Educação, Secretaria de Educação Básica.

Brasil. (2017). Base Nacional Comum Curricular (BNCC). Brasília: Ministério da Educação, Secretaria de Educação Básica.

César, A., \& Cavalcanti, M. (2007). Do Singular para o Multifacetado: o conceito de língua como Caleidoscópio. In M. Cavalcanti, \& S. Bortoni-Ricardi (Orgs.) Tranculturalidade, Linguagem e Ensino (pp. 45-66), Campinas: UNICAMP.

\section{Notes}

Note 1. We chose Heterodiscourse translation rather than Heteroglossia in this work.

Note 2. It was decided not to translate the term by Translinguaguem, for example, by seeming to be thinking of language and Translanguaging is an action, having no fixation. 


\section{Macrothink

\section{Copyright Disclaimer}

Copyright reserved by the author(s).

This article is an open-access article distributed under the terms and conditions of the Creative Commons Attribution license (http://creativecommons.org/licenses/by/3.0/). 